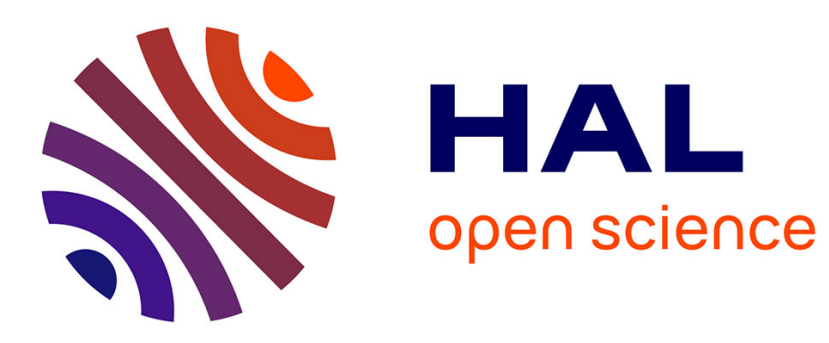

\title{
Endothelial cell chimerism associated with graft rejection after human lung transplantation.
}

Philippe Ratajczak, Hideyuki Murata, Véronique Meignin, Odile Groussard, Michel Fournier, Gérard Socié, Hervé Mal, Anne Janin

\section{- To cite this version:}

Philippe Ratajczak, Hideyuki Murata, Véronique Meignin, Odile Groussard, Michel Fournier, et al.. Endothelial cell chimerism associated with graft rejection after human lung transplantation.. Transplantation, 2008, 85 (1), pp.150-4. 10.1097/01.tp.0000297246.63022.71 . inserm-00172289

\section{HAL Id: inserm-00172289 https://www.hal.inserm.fr/inserm-00172289}

Submitted on 23 May 2014

HAL is a multi-disciplinary open access archive for the deposit and dissemination of scientific research documents, whether they are published or not. The documents may come from teaching and research institutions in France or abroad, or from public or private research centers.
L'archive ouverte pluridisciplinaire HAL, est destinée au dépôt et à la diffusion de documents scientifiques de niveau recherche, publiés ou non, émanant des établissements d'enseignement et de recherche français ou étrangers, des laboratoires publics ou privés. 


\section{HAL author manuscript}

Endothelial cell chimerism associated with graft rejection after human lung transplantation.

Hideyuki Murata ${ }^{1,2} *$, Philippe Ratajczak ${ }^{1,2} *$, Véronique Meignin ${ }^{1,2,5}$, Odile Groussard ${ }^{3}$, Michel Fournier ${ }^{4}$, Gérard Socié ${ }^{1,2,5}$, Hervé Mal ${ }^{4}$, Anne Janin ${ }^{1,2,5}$.

Key words: chimerism, endothelial cells, graft rejection, lung transplantation

Word counts of the abstract: 147

Word counts of the text: 1496

Table 1: Clinical And Pathological Features Of The Six Male Patients With Female Lung

Transplant, and Number of Chimeric, XY Labeled, Endothelial Cells And Alveolar

Macrophages In The Lung Transplants.

Figure 1. Endothelial Chimeric Cells Observed With Combined XY FISH And Immuno-

Stainings In A Biopsy From A Female Lung Transplanted In A Male. 
Manuscript ID TPE-2007-0255, revised manuscript

Footnotes:

Footnotes to The Title:

The work was supported by Inserm, Université Paris VII Denis Diderot, Legs Poix, Région Ile-de-France, PHRC, Agence de la Biomédecine, and LRC from CEA.

All authors declare no conflict of interest.

Footnotes to Authors' names:

1 Inserm, U728, Paris, F-75010, France ; 2 Université Paris 7, U728, Paris, F-75010, France ;

3 AP-HP, Hôpital Beaujon, Department of Pathology, Paris, F-75010, France ; 4 AP-HP, Hôpital Bichat, Department of Pneumology, Paris, F-75010, France ; 5 AP-HP, Hôpital SaintLouis, Department of Pathology, Paris, F-75010, France.

* H.M. and P.R. contributed equally to this work.

Corresponding author:

Anne Janin, Laboratoire de Pathologie, U728, Hôpital Saint-Louis, 1 Avenue Claude Vellefaux, 75475 Paris Cedex 10, France; e-mail: anne_janin@yahoo.com

Phone: (+33) 142499800

Fax: (+33) 142499281 
Manuscript ID TPE-2007-0255, revised manuscript

Abbreviations:

FISH: Fluorescent in situ Hybridation

HSCT: Hematopoietic Stem Cell Transplantation 
Manuscript ID TPE-2007-0255, revised manuscript

\section{Abstract}

Background: Endothelitis is a major sign of graft rejection. Recipient-derived endothelial cells found in two series of liver and kidney transplants were related to graft rejection. Here, we assessed the presence and the number of chimeric endothelial cells in lung transplants, and their relation with graft rejection.

Methods: In six males grafted with female lungs out of 193 lung transplantations, endothelial chimerism was studied by combined XY FISH with CD31 and CD45 immunostainings, and blood group antigens.

Results: On samples graded according to the revised working formulation for lung allograft rejection, we found chimeric macrophages (73.1 to $87.2 \%$ ) in all cases and chimeric endothelial cells (1.3 to 2.1\%) in four patients. Another method using ABO blood group also showed endothelial cells positive for recipient-type blood group antigens in three patients. By both methods, presence of chimeric endothelial cells was related to pathological signs of acute rejection $(\mathrm{p}<0.05)$ 
According to the revised working formulation for lung allograft rejection (1), "endothelitis" is the hallmark of acute graft rejection. In the transplanted organ, a variety of insults including organ preservation, surgical trauma (2), ischemia-reperfusion (3, 4), and alloimmune responses to donor antigens (5) can induce endothelial damage. The repair process can include recipient-derived endothelial cells as reported in liver (6), kidney (7) or heart transplants $(8)$. HLA or ABO markers have been used to determine donor or recipient origin of cells after transplantation. However combined XY-FISH and immunostainings in sexmismatched transplanted patients is a reference method (9-12). We used both methods to study lung endothelial chimerism of six male patients transplanted with female lungs. Out of 193 lung-transplanted patients in a single center (Hôpital Beaujon) between 1988 and 2005, we studied 6 male patients grafted with female lungs. Available pathological samples were either 88 biopsies, performed for diagnostic purpose, or blocks from two autopsies. Transplanted patients had one to seven sequential biopsies during the follow-up; and one to seven samples were taken for each sequential biopsy.

A double-blind evaluation of microscopic lesions was performed by two pathologists (HM, $\mathrm{AJ})$, according to the revised working formulation for lung allograft rejection (1). For chimerism study, only paraffin blocks of biopsies with enough remaining lung tissue were analyzed. This reduced the number of biopsy studied to 33 biopsies.

Chimerism was first studied with combined XY-FISH with CD31 (endothelial cells) or CD68 (macrophages) immunohistochemical staining and CD45 (lymphocyte) immunofluorescent staining as previously described $(11,13)$.

Tissue sections were analyzed by two pathologists (HM, AJ) and pictures captured at three different levels through a Z-stacking motorized system using Olympus-Analysis software. Chimeric cells were characterized using strict analytic criteria in Z-stacking analysis: in the same optical planes than $\mathrm{X}$ and $\mathrm{Y}$ chromosomes, endothelial cells had nucleus fully 
Manuscript ID TPE-2007-0255, revised manuscript

surrounded by cytoplasm, CD31-positive and CD45-negative cytoplasmic membrane; macrophages had nucleus fully surrounded by cytoplasm, CD68-positive and CD31-negative cytoplasmic membrane.

$\mathrm{XX}$ and XY signals were counted on ten different fields at $\mathrm{x} 100$ in a minimum of 500 cells for both endothelial cells and alveolar macrophages. A correction factor to assess the XYpositive cells frequency was calculated by analyzing chimerism on male control lung biopsies, where $76 \%$ of endothelial cells and $79 \%$ of alveolar macrophages were positive for $\mathrm{X}$ and $\mathrm{Y}$ chromosomes. Therefore the correction factor was 1.31 for endothelial cells and 1.26 for alveolar macrophages.

Chimerism was also studied with anti-blood group antigens A, B or H (T36, CLCP-19B, 17206 clones respectively, Interchim, France) on serial sections realized with an automaticmotorized microtome with water flow (HM350S, Microm, France). Normal lung specimens from surgical pieces with known blood group were used as positive controls, an irrelevant antibody as negative control. Tissue sections were analyzed on the motorized microscope and pictures captured on the same areas of sister following sections. Using Olympus-software, each immunostaining of the two successive sections was replaced in a different color and the final pictures were overlaid.

For statistical analyses, the chi-square test was used to determine any significant association between chimerism and the concomitant allograft rejection grading. Six male patients (58-68, median 60.5), transplanted for pulmonary fibrosis or emphysema, had received female lung transplants (Table 1).

Biopsies were performed 8 to 117 days after transplantation for diagnostic purpose. Using revised working formulation, signs of acute graft rejection were found in 10 of 33 biopsies with enough lung tissue available for chimerism studies. ABO group status showed a donor/recipient discrepancy between in four cases. 
Chimerism analysis of was first performed by combined XY-FISH with immunostainings and in these female lung transplants, cells were considered chimeric when they expressed both $\mathrm{X}$ and Y chromosomes. Chimeric cells were considered as endothelial cells when, on the combined XY-FISH and double immunostaining method, they expressed CD31, but not CD45 (Figure 1A, 1B).

XY signals were counted for endothelial cells and alveolar macrophages (Table 1). Chimeric alveolar macrophages were found for all patients with a frequency varying from 73.1 to $87.2 \%$, after correction. In 23 biopsies, no chimeric endothelial cells were found even after careful Z-stacking image analysis. In 10 biopsies and two autopsies, chimeric endothelial cells were found with a frequency varying from 1.3 to $2.1 \%$, after correction (Table 1 ).

Chimerism analysis was also performed with $\mathrm{ABO}$ group antibodies for the four blood groupmismatched patients ( 21 biopsies with enough biological material, 2 autopsies). Sisterfollowing sections stained with anti-ABO antibodies were analyzed according to the donor and recipient blood groups. Recipient-type endothelial cells were observed in eight biopsies from patients 2, 3 and 6. Interestingly, in the same microscopic areas, some capillaries were recipient-type positive when others were donor-type positive (Figure 1C). On digital pictures, each immunostaining of the same areas in the two successive sections was replaced in a different color and the final pictures overlaid. The overlay confirmed the coexistence of recipient-type and donor-type capillaries in the same microscopic field (Figure 1D).

Patients 1 and 2 had both biopsies and autopsies; endothelial cell chimerism appeared in the second biopsy of patient 1 and persisted in autopsy 15 days later; chimeric endothelial cells count was similar in biopsy and autopsy of patient 2 . No chimeric endothelial cells were found in three successive biopsies of patients 4 and 5. Endothelial cell chimerism was detected on the fourth (Day 62) and sixth (Day 61) biopsy and remained stable on the eighth (Day 117) and last biopsy performed in patients 3 and 6. 
In the 33 biopsies and two autopsies studied, chimeric endothelial cells were only found in the 10 samples with pathological signs of lung allograft rejection whereas chimeric alveolar macrophages were present in all samples (Table 1). This strong link between presence of chimeric endothelial cells and graft rejection was also observed with blood group analysis $(p<0.05)$. Recipient-type endothelial cells were only found in the three patients with ABO incompatibilities and signs of graft rejection.

Chimeric cells in human pulmonary epithelium have been reported in 6 out 8 sex-mismatched lung transplanted males with chronic graft rejection (14) but no count was performed and no correlation with the pathologic signs of lung allograft rejection could be established. Chimeric cells were also found in lymphocytes and macrophages populations, but not in epithelial or endothelial cells in three sex-mismatched lung transplanted males (15). This discrepancy with our results may be linked to the method used.

XY-FISH analysis, performed on sequential bronchial biopsies in two children with sexmismatched lung transplant, showed that chimeric epithelial cells were present and that their number was stable over time (16). Endothelial cells were not characterized in this study. In the sequential biopsies we studied, chimeric endothelial cells, when present, remained in the successive biopsies

Our Z-stacking method allowed a precise count of chimeric cells. We detected chimeric alveolar macrophages in large numbers, rather similar to reported numbers in lung-transplant bronchoalveolar lavages $(17,18)$.

For chimeric endothelial cells, as far as we know, counts have only been performed in heart and liver transplantations. Numbers vary from $0.1 \pm 0.01 \%(19)$ to $24.3 \pm 8.2 \%(8)$ in hearttransplants, and from 42 to $61 \%$ (20) in liver-transplants. After hematopoietic stem cell transplantation, numbers of chimeric endothelial cells in bronchial biopsies (37.5-42.3\%) (21) was higher than numbers we found (1.3-2.1\%) in our series of transplanted lungs. This 
discrepancy can be linked to the type of allograft since hematopoietic stem cells can differentiate into endothelial cells (22).

We used a second technical approach to detect the presence of chimeric endothelial cells. Laser microdissection followed by PCR of one polymorphic short tandem repeat marker, requiring a minimum of 500 laser-microdissected cells from cryopreserved sections (23), could not be performed. Antibodies directed against $\mathrm{ABO}$ blood group antigens $(7,24)$ were used for lung samples of patients with discrepancies between donor and recipient blood group status. A complete analysis with the two different methods could be performed in four patients and gave similar results.

Interestingly, there was a strong correlation between pathological signs of lung allograft rejection and presence of chimeric endothelial cells. This correlation also found in two series of liver (24) and kidney (7) transplantation has not been, as far as we know, reported in transplanted-lung, though in this organ, links between microvascular damage and obliterative bronchiolitis or chronic pulmonary hypertension are discussed $(25,26)$. The presence of chimeric endothelial cells only in the four patients with lung graft rejection in our series may be linked to tissue repair after endothelial damage.

Two mechanisms have been described in endothelial cell repair: local migration and proliferation of endothelial cells adjacent to the injury site; and homing and incorporation of endothelial progenitor cells in the injury site (27). Our results suggest the participation of recipient-derived cells in endothelial repair of graft rejection-induced lung damage. This is in accordance with what has been reported in kidney (7), liver (24), and heart (8) transplants. In conclusion, the new methods of endothelial cell studies in organ transplants open a field of investigation with important consequences regarding graft tolerance and rejection, and their therapeutic modulation. 
Manuscript ID TPE-2007-0255, revised manuscript

\section{References}

1. Yousem SA, Berry GJ, Cagle PT, et al. Revision of the 1990 working formulation for the classification of pulmonary allograft rejection: Lung Rejection Study Group. J Heart Lung Transplant 1996; 15 (1 Pt 1): 1.

2. Halloran PF. Non-immunologic tissue injury and stress in chronic allograft dysfunction. Graft 1998; 1: 25.

3. Fellstrom B, Akyurek ML, Larsson F, Waltenberger J, Wanders A, Funa K. Ischemia induced upregulation of growth factor expression in experimental transplant arteriosclerosis. Transplant Proc 1997; 29 (6): 2558.

4. Grinyo JM. Reperfusion injury. Transplant Proc 1997; 29 (1-2): 59.

5. Hutchinson IV. Cardiac allograft vasculopathy--the cellular attack. Z Kardiol 2000; 89 Supp1 9: IX/16.

6. Hove WR, van Hoek B, Bajema IM, Ringers J, van Krieken JH, Lagaaij EL. Extensive chimerism in liver transplants: vascular endothelium, bile duct epithelium, and hepatocytes. Liver Transpl 2003; 9 (6): 552.

7. Lagaaij EL, Cramer-Knijnenburg GF, van Kemenade FJ, van Es LA, Bruijn JA, van Krieken JH. Endothelial cell chimerism after renal transplantation and vascular rejection. Lancet 2001; 357 (9249): 33.

8. Minami E, Laflamme MA, Saffitz JE, Murry CE. Extracardiac progenitor cells repopulate most major cell types in the transplanted human heart. Circulation 2005; 112 (19): 2951.

9. Nagler A, Ilan Y, Amiel A, Eid A, Tur-Kaspa R. Systemic chimerism in sexmismatched liver transplant recipients detected by fluorescence in situ hybridization. Transplantation 1994; 57 (10): 1458. 
Manuscript ID TPE-2007-0255, revised manuscript

10. $\mathrm{Ng} \mathrm{IO}$, Chan KL, Shek WH, et al. High frequency of chimerism in transplanted livers. Hepatology 2003; 38 (4): 989

11. Murata H, Janin A, Leboeuf C, et al. Donor-derived cells and human graft-versus-host disease of the skin. Blood 2006; 109 (6): 2663

12. Thiele J, Varus E, Wickenhauser C, Kvasnicka HM, Metz KA, Beelen DW. Regeneration of heart muscle tissue: quantification of chimeric cardiomyocytes and endothelial cells following transplantation. Histol Histopathol 2004; 19 (1): 201.

13. Meignin V, Soulier J, Brau F, et al. Little evidence of donor-derived epithelial cells in early digestive acute graft-versus-host disease. Blood 2004; 103 (1): 360.

14. Albera C, Polak JM, Janes S, et al. Repopulation of human pulmonary epithelium by bone marrow cells: a potential means to promote repair. Tissue Eng 2005; 11 (7-8): 1115

15. Bittmann I, Dose T, Baretton GB, et al. Cellular chimerism of the lung after transplantation. An interphase cytogenetic study. Am J Clin Pathol 2001; 115 (4): 525.

16. Spencer H, Rampling D, Aurora P, Bonnet D, Hart SL, Jaffe A. Transbronchial biopsies provide longitudinal evidence for epithelial chimerism in children following sex mismatched lung transplantation. Thorax 2005; 60 (1): 60 .

17. Wiebe BM, Mortensen SA, Petterson G, Svendsen UG, Andersen CB. Macrophage and lymphocyte chimerism in bronchoalveolar lavage cells from human lung allograft recipients. Apmis 2001; 109 (6): 435.

18. Rothmeier C, Roux E, Spiliopoulos A, Gerbase M, Nicod LP. Early chimerism of macrophages and lymphocytes in lung transplant recipients is predictive of graft tolerance. Transplantation 2001; 71 (9): 1329. 
Manuscript ID TPE-2007-0255, revised manuscript

19. Hocht-Zeisberg E, Kahnert H, Guan K, et al. Cellular repopulation of myocardial infarction in patients with sex-mismatched heart transplantation. Eur Heart J 2004; 25 (9): 749

20. Pons JA, Yelamos J, Ramirez P, et al. Endothelial cell chimerism does not influence allograft tolerance in liver transplant patients after withdrawal of immunosuppression. Transplantation 2003; 75 (7): 1045.

21. Suratt BT, Cool CD, Serls AE, et al. Human pulmonary chimerism after hematopoietic stem cell transplantation. Am J Respir Crit Care Med 2003; 168 (3): 318.

22. Khakoo AY, Finkel T. Endothelial progenitor cells. Annu Rev Med 2005; 56: 79.

23. Zhao WL, Daneshpouy ME, Mounier N, et al. Prognostic significance of bcl-xL gene expression and apoptotic cell counts in follicular lymphoma. Blood 2004; 103 (2): 695.

24. Tanaka $\mathrm{Y}$, Haga $\mathrm{H}$, Egawa $\mathrm{H}$, et al. Intragraft expression of recipient-type ABO blood group antigens: long-term follow-up and histological features after liver transplantation. Liver Transpl 2005; 11 (5): 547.

25. Arciniegas E, Frid MG, Douglas IS, Stenmark KR. Perspectives on endothelial-tomesenchymal transition: potential contribution to vascular remodeling in chronic pulmonary hypertension. Am J Physiol Lung Cell Mol Physiol 2007; 293 (1): L1.

26. Luckraz H, Goddard M, McNeil K, Atkinson C, Sharples LD, Wallwork J. Is obliterative bronchiolitis in lung transplantation associated with microvascular damage to small airways? Ann Thorac Surg 2006; 82 (4): 1212.

27. Woywodt A, Bahlmann FH, De Groot K, Haller H, Haubitz M. Circulating endothelial cells: life, death, detachment and repair of the endothelial cell layer. Nephrol Dial Transplant 2002; 17 (10): 1728 . 
Manuscript ID TPE-2007-0255, revised manuscript

Figures and tables:

Figure 1. Endothelial Chimeric Cells In A Biopsy From A Female Lung Transplanted In A Male.

A and B: Combined immunohistochemistry (with an antibody directed against CD31, a specific maker for endothelial cells), XY Fluorescent In Situ Hybridization and immunofluorescence (with an antibody directed against CD45, a specific maker for leukocytes) on the same section of grafted female lung (line A). Chimeric endothelial cells (maked E) defined by the combined expression of XY and CD31 but not CD45 (overlay of line B) can be distinguished from leukocytes from the same recipient (marked L), characterized by the combined expression of XY and CD45, but nor CD31. (A and B: bar = $10 \mu \mathrm{m})$

$\mathrm{C}$ and D: Immunohistochemistry in serial sections of a lung biopsy from a female with type blood $\mathrm{O}$ grafted in a recipient with type blood $\mathrm{A}$.

lane $\mathrm{C}$ : in two serial sections of a bronchial area, antibodies directed against antigen $\mathrm{A}$ and antigen $\mathrm{H}$ show stainings on capilary sections at different sites of the lamina propria.

lane D: higher magnification of the areas of the lamina propria delimited by broken lines in pictures of lane $\mathrm{C}$. In the middle of lane $\mathrm{D}$, an overlay of the areas of the lamina propria delimited by broken lines in pictures on $\mathrm{C}$ was performed, using color replacement of specific labeling with antigen $\mathrm{A}$ and $\mathrm{H}$ in green and red respectively, following modification of a method used by Tanaka and al. (29). This overlay shows on D the presence in the same microscopic field, of both recipient capillaries in green, and donor capillaries in red. (C and D $\operatorname{bar}=100 \mu \mathrm{m})$

Table 1: Clinical And Pathological Features Of The Six Male Patients With Female Lung Transplant, and Number of Chimeric, XY Labeled, Endothelial Cells And Alveolar Macrophages In The Lung Transplants. 